\title{
Biodeterioration Studies of Thermoplastics in Nature using Indigenous Bacterial Consortium
}

\author{
Mohd. Shahbaz Anwar ${ }^{1}$, Harshita Negi ${ }^{1}$, Mohd. Ghulam Haider Zaidi ${ }^{2}$, Sanjay Gupta ${ }^{3}$ and \\ Reeta Goel ${ }^{*}$ \\ ${ }^{I}$ Department of Microbiology; C.B.S.H., G. B. Pant University of Agriculture and Technology; Pantnagar-263145; \\ Uttarakhand - India. ${ }^{2}$ Department of Chemistry; C.B.S.H., G. B. Pant University of Agriculture and Technology; \\ Pantnagar-263145; Uttarakhand - India. ${ }^{3}$ Department of Biotechnology; S.B.S.P.G.I., Balawala, Dehradun; \\ Uttarakhand - India
}

\begin{abstract}
Thermoplastics, poly vinyl chloride and low-density polyethylene were treated in the presence of indigenously developed bacterial consortium in laboratory and natural conditions. The consortium was developed using four bacteria, selected on the basis of utilization of PVC as primary carbon source, namely P. otitidis, B. aerius, B. cereus and A. pedis isolated from the plastic waste disposal sites in Northern India. The comparative in-vitro treatment studies as revealed by the spectral and thermal data, illustrated the relatively better biodegradation potential of developed consortium for PVC than the LDPE. Further, the progressive treatments of both the thermoplastics were conducted for three months under natural conditions. For this purpose, bioformulation of consortium was prepared and characterized for the viability up to 70 days of storage at $25 \pm 1^{\circ} C$. The consortium treated polymer samples were monitored through SEM and FT-IR spectroscopy. Analytical data revealed the biodeterioration potential of the developed consortium for PVC and LDPE, which could help in disposing the plastic waste.
\end{abstract}

Key words: Biodeterioration, Bioformulation, Thermoplastic, FT-IR, SEM, TG-DTG-DTA

\section{INTRODUCTION}

Nowadays, wider applications of thermoplastics with particular emphasis on poly vinyl chloride (PVC) and low-density polyethylene (LDPE) in domestic, scientific and technological applications have raised serious issue of waste disposal, leading to pollution (Kawai 2010). Over the past few years, stabilization and degradation of such recalcitrant thermoplastic-based materials and issues related to their applications, health, safety and environmental impact have been of immense academic and technological interest. In this context, among various strategies of degrading recalcitrant polymers, biodeterioration and biodegradation offer a mild means for their recycling and disposal (Wypych 2008; Arutchelvi et al. 2008; Yoon et al. 2012; Sharon and Sharon 2012). Although, biodegradation is necessary for both water-soluble and water-immiscible polymers because they eventually enter the streams, which can neither be recycled nor incinerated (Barnes et al. 2009). Several microorganisms such as Pseudomonas aeruginosa, Aureobasidium pullalans, Rhodotorula aurantiaca and Kluyveromyces sp. have been reported to cause in situ colonization and substratum deterioration of plasticized PVC (Booth and Robb 2007). Further,

*Author for correspondence: rg55@ rediffmail.com 
the colonization of $A$. pullulans displays a significant substratum damage of the plasticized PVC, followed by $R$. aurantiaca and Kluyveromyces sp., suggesting that microbial succession occurs during the colonization process and that A. pullulans has been critical to the establishment of a microbial community on the polymers (Webb et al. 2000). The plasticizer content of PVC has been reported to degrade in the presence of $P$. fluorescens (Zeng et al. 2002), Coryneform bacterium and Mycobacterium sp. (Nakamiya et al. 2005). The blend of $\mathrm{PVC} /$ polycaprolactone has also been reported to degrade in the presence of Curvularia sp., Trogia buccinalis and Phanerochaete chrysosporium (Sandra et al. 2010).

Similarly, polyethylene's has been reported to degrade in the presence of Pseudomonas, Streptococcus, Staphylococcus, Micrococcus (Kathiresan 2003, Yoon et al. 2012), Xanthomonas, Flavobacterium, Agrobacterium and Bacillus sps (Gupta et al. 2010). However, degradation of thermoplastic in natural condition is a global challenge of this time (Nowak et al. 2011). Hence, there is an urgent need to develop efficient consortia and their products to solve the burning issue, i.e., plastic waste management in nature. Thus, the present study focused on the in vitro and in situ treatment of two thermoplastics in the presence of potential bacterial strains and their bioformulation, respectively.

\section{MATERIALS AND METHODS}

\section{Starting Materials}

PVC and LDPE beads were procured from SigmaAldrich Inc., St. Louis, MO, U.S.A. and converted into powdered form by boiling with xylene, followed by solvent evaporation at room temperature $\left(28^{\circ} \mathrm{C}\right)$. The powdered form was successively washed with $70 \%$ ethanol and dried at $50 \pm 1^{\circ} \mathrm{C}$ for $1 \mathrm{~h}$ and used as a primary carbon source for in vitro studies. The above processing was done in order to increase the surface area of polymer for better interaction with the bacteria in the liquid medium. Further, commercially available PVC and LDPE films were also used for the in situ studies. The talc, which was used as a carrier for bioformulation preparation was purchased from HiMedia Lab Pvt. Ltd, Mumbai, India. It was composed of talcum steatite, talc fine powder and hydrous magnesium silicate. Nutrient broth (HiMedia, India) was taken as medium for the bacterial growth and Minimal broth Davis without (w/o) dextrose (HiMedia, India) as the medium for the in vitro studies.

\section{Bacterial Consortium}

A total of four bacterial cultures were retrieved from the departmental culture collection of Microbiology, CBSH, G. B. Pant University of Agriculture and Technology, Pantnagar, India (Table 1). These cultures were selected on the basis of their pre-identified potential to act upon PVC (Anwar 2011) and LDPE (Kapri et al. 2010). The cultures were revived on nutrient broth and maintained on nutrient agar at optimum initial $\mathrm{pH}$ $(7.0 \pm 0.2)$ and temperature $\left(37^{\circ} \mathrm{C}\right)$. A single colony of each bacterial culture was inoculated into 50 $\mathrm{mL}$ flask containing $10 \mathrm{~mL}$ of nutrient broth and active cultures were prepared by incubating the flask for $16 \mathrm{~h}$ with continuous shaking at $120 \mathrm{rpm}$. The calculated amount $\left(\mathrm{cfu} \mathrm{mL}^{-1}\right)$ of each strain was mixed for the development of consortium. The compatibility of the used strains for the preparation of the consortium was tested and reported earlier (Satlewal et al. 2008; Negi et al. 2009; Soni et al. 2009; Goel et al. 2010; Kapri et al. 2010; Anwar 2011; Goel et al. 2011).

Table 1 - Bacterial strains used in the study.

\begin{tabular}{lc}
\hline Bacterial strains & Accession no. \\
\hline Pseudomonas otitidis strain SPT1 & GU598256 \\
Bacillus aerius strain SPT2 & GU598257 \\
Acanthopleuribacter pedis strain SPT3 & GU598258 \\
Bacillus cereus strain SPK1 & GU598261 \\
\hline
\end{tabular}

Laboratory Scale Treatment of Thermoplastics

For the in vitro studies, $100 \mathrm{~mL}$ Minimal broth Davis w/o dextrose $(\mathrm{pH} 7.0 \pm 0.2)$ was taken in five $250 \mathrm{~mL}$ Erlenmeyer flasks. One flask containing $300 \mu \mathrm{l}$ of active consortium in the absence of any polymer was taken as positive 
control. Two flasks containing PVC and LDPE powder (added separately) at a concentration of $5.0 \mathrm{mg} / \mathrm{mL}$ without the consortium were taken as negative control. The remaining two inoculated with above said amount of consortium and both the polymers separately were taken as the experimental flasks. All the flasks were incubated at $37^{\circ} \mathrm{C}$ with continuous shaking $(120 \mathrm{rpm})$. The shift in $\lambda$-max in the treatments and negative controls was determined after the regular intervals of $24 \mathrm{~h}$ during the incubation period, till the consortium attained the stationary phase. The treated samples were recovered from the broth through the filtration of flask content and then the filtrate as well as the residue was collected separately. The filtrate was centrifuged at 5000 rpm for $15 \mathrm{~min}$ to remove the bacterial biomass and the supernatant was kept in an oven at $50^{\circ} \mathrm{C}$ for overnight to evaporate the water and the residual samples was recovered and analyzed.

\section{Treatment in Natural Condition \\ Preparation and viability determination of talc- based bioformulation}

Prepared active consortium (200 mL) was spun at $5000 \mathrm{rpm}$ for $15 \mathrm{~min}$ to remove the bacterial cells. Then, $10 \mathrm{~g}$ talc was weighed and added to the pellets under sterile conditions and mixed properly. The mixture was then kept at room temperature $\left(28 \pm 1^{\circ} \mathrm{C}\right)$ aseptically for drying. The viability of bacterial isolates in the bioformulation was ascertained by serial dilution plating method. For this purpose, $1.0 \mathrm{~g}$ of talc-based formulation was mixed in $1.0 \mathrm{~mL}$ of sterile distilled water. The suspension was further mixed with $9.0 \mathrm{~mL}$ of sterilized distilled water. Likewise, the dilution plating was done in nutrient agar medium. The plates were incubated at $37 \pm 1^{\circ} \mathrm{C}$ and the cfu mL counts were checked initially after 2 and 4 days. Thereafter, the viability was determined after regular interval of 7 days for subsequent three weeks, followed by 15 days interval. The above pattern was followed keeping in view the rapidity of changes in viable counts during the storage. The plate counts were carried out in triplicates and the average of the three respective readings were taken.

\section{In-situ treatment}

Top-soil was dug from a barren land at Pantnagar, India, autoclaved at $121^{\circ} \mathrm{C}$ for 25 minutes and then filled into $45 \times 34 \mathrm{~cm}^{2}$ sinks. The PVC and LDPE film coupons of dimensions $2.5 \times 2.5 \mathrm{~cm}^{2}(1.0$ inch $^{2}$ ) were surface sterilized with ethanol (70\%) for $10 \mathrm{~min}$ and subsequently mounted vertically inside the soil at varying depths. The soil of the respective treatments was inoculated with the bioformulation and incubated in natural condition. The moisture and aeration in the experimental sinks were taken care by adding autoclaved distilled water and shovelling the soil at regular intervals of two weeks. The PVC and LDPE film coupons incubated in the soil devoid of bacterial consortium were taken as control. Both the film coupons were kept in soil for three months, thereafter recovered and then sterilized with ethanol (70\%) for $10 \mathrm{~min}$ and dried in a desiccator for $24 \mathrm{~h}$ under vacuum.

\section{Analysis of Treated Polymer Samples}

The changes in the polymer samples treated were preliminary determined by measuring the $\lambda$-max shift in comparison to negative control through Perkin Elmer UV-Vis Spectrophotometer. In order to eliminate the discrepancy between the consortium-treated polymer samples and their untreated controls, the thermal properties were studied through simultaneous thermogravimetric (TG)-differential thermogravimetric (DTG)differential thermal analysis (DTA) over Perkin Elmer (Pyris Diamond) thermal analyzer under nitrogen atmosphere $\left(200 \mathrm{~mL} \mathrm{~min}{ }^{-1}\right)$ from 50 to $1000^{\circ} \mathrm{C}$ with heating rate of $5^{\circ} \mathrm{C} \mathrm{min}^{-1}$ on a platinum pan. The weight loss $(\%)$ of the samples was evaluated as a function of temperature through TGA. The temperature with the maximum weight loss was illustrated as DTG peak temperature and the heat of degradation $(\Delta \mathrm{H})$ involved in the thermal behaviour of the samples representing the exotherm and endotherm was estimated through DTA.

The chemical changes in the residuals and the recovered polymer films obtained after the treatment were determined through Perkin Elmer Fourier transform infrared (FT-IR) Spectrophotometer and the spectra were recorded on $\mathrm{KBr}$ disc, taking pure PVC and LDPE as the references. The change in the morphology of the recovered polymer films were ascertained through the microscopy studies. For this purpose, the samples were metallized with gold particles (three discharges of $40 \mathrm{~mA} / 50 \mathrm{~s}$ in argon atmosphere) in a high vacuum metalizator (Bal-Tec SCD 005) and analyzed by scanning electron microscopy (SEM) (Leo, 435VF, U.K.) at $15.00 \mathrm{kV}$ EHT under three successive magnifications (1.5, 3.0 and 5.0 KX). 


\section{RESULTS AND DISCUSSION}

\section{Comparative Growth Profiling of Consortium}

The growth profile of the used consortium, compared in the absence and presence of the polymers (PVC and LDPE) revealed that both the polymers didn't affect the growth pattern of the consortium as stationary phase was achieved within two days, as in case of control (Table 2). However, in the presence of polymers, the consortium showed reduction of lag phase by $24 \mathrm{~h}$, earlier onset of log phase and more biomass (revealed by the $\mathrm{OD}_{600}$ ), which indicated the sustained growth of consortium as compared to the control (Figures $1 \mathrm{~A}, \mathrm{~B}$ ). Further, a prominent shift in $\lambda$ max of PVC (from $206.3 \mathrm{~nm}$ to $218.84 \mathrm{~nm}$ ) was observed within $24 \mathrm{~h}$ of incubation and subsequently attained a value of $218.84,218.15$ and $217.13 \mathrm{~nm}$ after a successive period of incubation, i.e., $3^{\text {rd }}, 4^{\text {th }}$ and $5^{\text {th }}$ day, respectively (Fig. 1A). However, shift in $\lambda$ max of LDPE (from $202.1 \mathrm{~nm}$ to $209.5 \mathrm{~nm}$ ) was observed after $2^{\text {nd }}$ day and subsequently up to $4^{\text {th }}$ days of incubation (Figure 1B). These findings suggested that the microbial action on PVC could be fast in comparison to the LDPE. Further, the results indicated that both the polymers were used by the bacterial consortium for their survival as the growth medium was not containing any other carbon source. Also, higher bacterial biomass and changes in the polymer structure were achieved during the incubation period as reported by Kapri et al. (2010) and Sah et al. (2010).

Table 2. Growth profile of bacterial consortium grown in the presence of PVC and LDPE as sole carbon source in liquid medium during incubation.

\begin{tabular}{|c|c|c|c|c|c|}
\hline \multirow{2}{*}{$\begin{array}{l}\text { Treatment } \\
\text { Consortium }\end{array}$} & \multirow{2}{*}{$\begin{array}{r}\text { Days } \\
0\end{array}$} & \multicolumn{3}{|c|}{$\mathrm{OD}_{600}$ values in triplicate } & \multirow{2}{*}{$\frac{\lambda \max }{-}$} \\
\hline & & 0.001 & 0.001 & 0.001 & \\
\hline Consortium & 1 & 0.016 & 0.015 & 0.014 & - \\
\hline Consortium & 2 & 0.13 & 0.12 & 0.14 & - \\
\hline Consortium & 3 & 0.11 & 0.11 & 0.12 & - \\
\hline Consortium & 4 & 0.08 & 0.09 & 0.08 & - \\
\hline Consortium & 5 & 0.114 & 0.115 & 0.116 & - \\
\hline Consortium + PVC & 0 & 0.001 & 0.001 & 0.001 & 203 \\
\hline Consortium + PVC & 1 & 0.196 & 0.195 & 0.192 & 204 \\
\hline Consortium + PVC & 2 & 0.17 & 0.18 & 0.18 & 206 \\
\hline Consortium + PVC & 3 & 0.17 & 0.16 & 0.17 & 207 \\
\hline Consortium + PVC & 4 & 0.162 & 0.161 & 0.16 & 208 \\
\hline Consortium + PVC & 5 & 0.163 & 0.162 & 0.161 & 209 \\
\hline Consortium + LDPE & 0 & 0.001 & 0.001 & 0.001 & 207 \\
\hline Consortium + LDPE & 1 & 0.134 & 0.135 & 0.133 & 216 \\
\hline Consortium + LDPE & 2 & 0.156 & 0.155 & 0.156 & 218 \\
\hline Consortium + LDPE & 3 & 0.153 & 0.152 & 0.154 & 219 \\
\hline Consortium + LDPE & 4 & 0.135 & 0.136 & 0.135 & 217 \\
\hline Consortium + LDPE & 5 & 0.182 & 0.183 & 0.182 & 216 \\
\hline
\end{tabular}
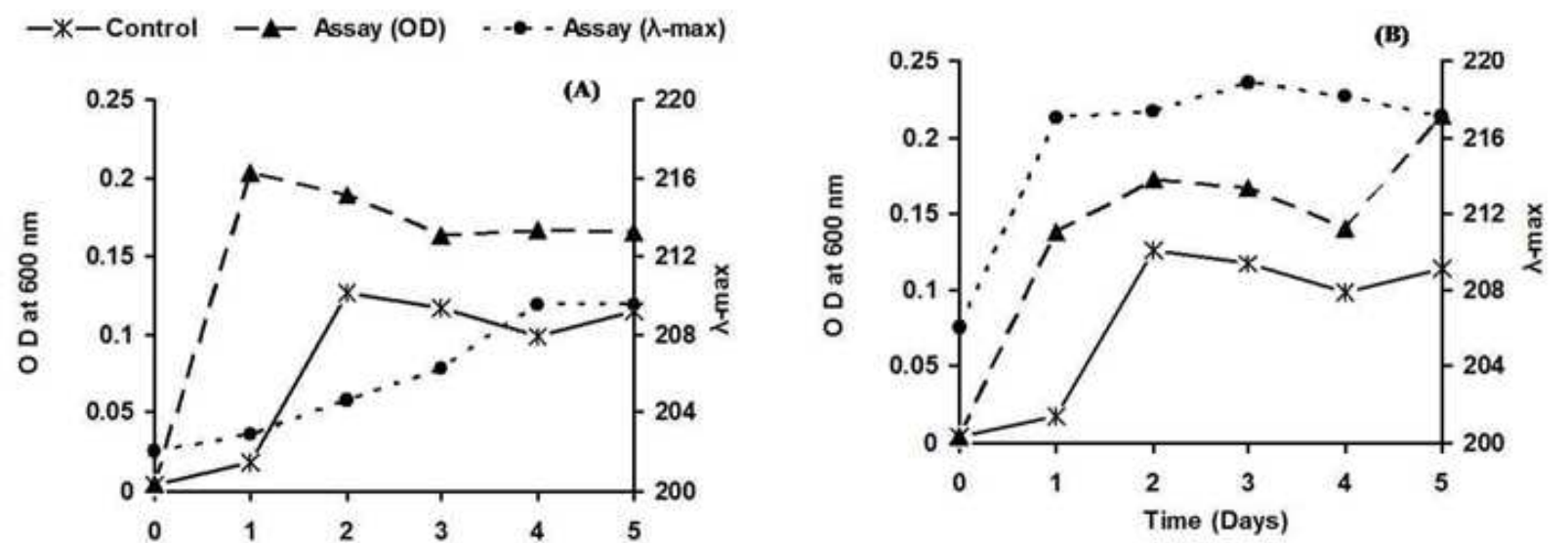

Figure 1 - Growth profile of bacterial consortium grown in the presence of PVC (A) and LDPE (B) as sole carbon source in liquid medium. 


\section{Shelf Life of Bioformulation}

The viability of the consortium was maintained in the talc-based bioformulation for a period of 70 days at ambient temperature (Table 3 ).

These observations suggested that the consortium was viable in the developed carrier-based formulation. The consortium in the form of powdered bioformulation was further used for the pilot-scale experiments. The viability test for
PGPR bioinoculants was also conducted by Arora et al. (2008), wherein sawdust was used as the carrier. The clay-based formulation of Pseudomonads for degrading the petrol has been reported by Ting et al. (2010). The talc as carrier has also been reported for PGPR strains for management of various plant pathogens (Shanmugam et al. 2011).

Table 3 - Shelf life of bioformulation under ambient storage temperature.

\begin{tabular}{cccccccc}
\hline \multicolumn{7}{c}{$\mathbf{C f u} / \mathbf{m l} *\left(\times \mathbf{1 0}^{\mathbf{6}}\right)$ at subsequent time intervals (days) } \\
\hline $\mathbf{2}^{\text {nd }}$ & $\mathbf{4}^{\text {th }}$ & $\mathbf{1 1}^{\text {th }}$ & $\mathbf{1 8}^{\text {th }}$ & $\mathbf{2 5}^{\text {th }}$ & $\mathbf{4 0}^{\text {th }}$ & $\mathbf{5 5}^{\text {th }}$ & $\mathbf{7 0}^{\text {th }}$ \\
\hline $223 \pm 2$ & $216 \pm 2$ & $210 \pm 2$ & $176 \pm 2$ & $171 \pm 2$ & $90 \pm 2$ & $76 \pm 2$ & $36 \pm 2$ \\
\hline
\end{tabular}

*Mean of three replicates.

\section{Analysis of Treated Polymers Simultaneous TG-DTG-DTA}

The thermal data of PVC and LDPE treated by the consortium with reference to control, are shown in Table 4.

The thermogram of control polymers showed single step decomposition. The thermal degradation of control PVC started at $301^{\circ} \mathrm{C}$ with weight loss (WL) of $3.1 \%$ and was terminated at $500^{\circ} \mathrm{C}$ with complete decomposition. The TG data was further supported by a DTG profile. A triplet was observed in DTG profile at temperature ranging $400-469^{\circ} \mathrm{C}$ with highest rate of decomposition $(0.111 \mathrm{mg} / \mathrm{min})$. It also showed a pair of DTA exotherm at $403^{\circ} \mathrm{C}(115 \mu \mathrm{V})$ and $476^{\circ} \mathrm{C}(104 \mu \mathrm{V})$ with heat of decomposition $\Delta \mathrm{H}$ (mJ/mg), 138 (Fig. 2A). In case of control LDPE, the thermal degradation started at $400^{\circ} \mathrm{C}$ with $4.5 \%$ WL and it was terminated at $466^{\circ} \mathrm{C}$ with weight residue of $0.6 \%$ as reported by Tajeddin et al. (2009). The single step thermal decomposition was observed with a DTG profile at $451^{\circ} \mathrm{C}$ and the rate of decomposition was $1.79 \mathrm{mg} / \mathrm{min}$. A pair of DTA endotherm has been reported at $107^{\circ} \mathrm{C}(-3$ $\mu \mathrm{V})$ and $457^{\circ} \mathrm{C}(-31.4 \mu \mathrm{V})$ with $\Delta \mathrm{H}, 129.0$ and $53.0 \mathrm{~mJ} / \mathrm{mg}$, respectively. Along with this temperature, a weak exotherm was also observed at $476^{\circ} \mathrm{C}(104 \mu \mathrm{V})$ with $\Delta \mathrm{H}-14.6 \mathrm{~mJ} / \mathrm{mg}$ (Fig. $2 \mathrm{~B}$ ).

Table 4 - Thermal analysis of consortium treated PVC and LDPE powder with reference to respective control.

\begin{tabular}{|c|c|c|c|c|c|c|}
\hline \multirow[t]{2}{*}{ Thermoplastic } & \multicolumn{2}{|r|}{ DTG Peak Temperature } & \multicolumn{2}{|c|}{ DTA Exotherm } & \multicolumn{2}{|c|}{ DTA Endotherm } \\
\hline & ${ }^{\circ} \mathrm{C}$ & Decomposition Rate $(\mu \mathrm{g} / \mathrm{min})$ & ${ }^{\circ} \mathrm{C}$ & $\Delta \mathbf{H}(\mathbf{m J} / \mathbf{m g})$ & ${ }^{\circ} \mathrm{C}$ & $\Delta \mathbf{H}(\mathrm{mJ} / \mathrm{mg})$ \\
\hline \multirow[t]{3}{*}{ PVC Control } & 400 & 101 & 403,476 & 6.28 & 132 & 138 \\
\hline & 436 & 111 & & & & \\
\hline & 469 & 930 & & & & \\
\hline \multirow[t]{2}{*}{ LDPE Control } & 451 & 1790 & 467 & 14.6 & 107 & 129 \\
\hline & & & & & 457 & 53 \\
\hline \multirow[t]{4}{*}{ Treated PVC } & 57 & 161.7 & - & - & 62 & 92.5 \\
\hline & 117 & 76.4 & & & 122,156 & 76.6 \\
\hline & 154 & 158.0 & & & 225 & 147 \\
\hline & 222 & 101.3 & & & 572,591 & 99.4 \\
\hline \multirow[t]{3}{*}{ Treated LDPE } & 148 & 710 & - & - & 149 & 155 \\
\hline & 218 & 150 & & & 224 & 92.2 \\
\hline & & & & & 576 & 83.4 \\
\hline
\end{tabular}

The consortium treated PVC was undergoes threestep decomposition with an early onset of thermal decomposition temperature. The first step of decomposition occurred at $65^{\circ} \mathrm{C}$, second step at $107^{\circ} \mathrm{C}$ and final step at $230^{\circ} \mathrm{C}$ with $4.6,5.4$ and $11.9 \%$ WL, respectively. The three steps decomposition was verified through three DTG profile with the highest rate of decomposition 
$(0.161 \mathrm{mg} / \mathrm{min})$ at $57^{\circ} \mathrm{C}$. The TG data was further supported by DTA endotherm at temperature ranging $62^{\circ} \mathrm{C}(-11.0 \mu \mathrm{v})$ to $225^{\circ} \mathrm{C}(-15.86 \mu \mathrm{V})$ with $\Delta \mathrm{H}, 92$ to $147 \mathrm{~mJ} / \mathrm{mg}$, respectively (Fig. 2C). However, for LDPE, two steps thermal decomposition was observed by the treated with consortium. The TG data revealed the first step decomposition at $120^{\circ} \mathrm{C}$ with $3.6 \% \mathrm{WL}$ and second step decomposition at $202^{\circ} \mathrm{C}$ with $16.8 \% \mathrm{WL}$. TG data was further verified through two DTG profile with the highest rate of decomposition (0.71 $\mathrm{mg} / \mathrm{min}$ ) at $148^{\circ} \mathrm{C}$. These data were further supported by a pair of DTA endotherm at temperature ranging $149^{\circ} \mathrm{C}(-17.7 \mu \mathrm{V})$ and $224^{\circ} \mathrm{C}$
$(-13.6 \mu \mathrm{V})$ with $\Delta \mathrm{H}, 155$ and $92.2 \mathrm{~mJ} / \mathrm{mg}$, respectively (Fig. 2D). However, the similar significant changes in the thermal profiles of biodegraded samples of polycarbonate (Goel et al. 2008) and LDPE (Sah et al. 2010) have been reported showing the biodegradation potential of the used consortium for PVC and LDPE. Thus, the consortium was responsible for multiple step decomposition, changes in the thermal profile and increased weight loss of the treated polymer. Further, the comparative analysis of the change in the thermal profiling suggested that the consortium could better use PVC as sole carbon source in comparison to the LDPE.
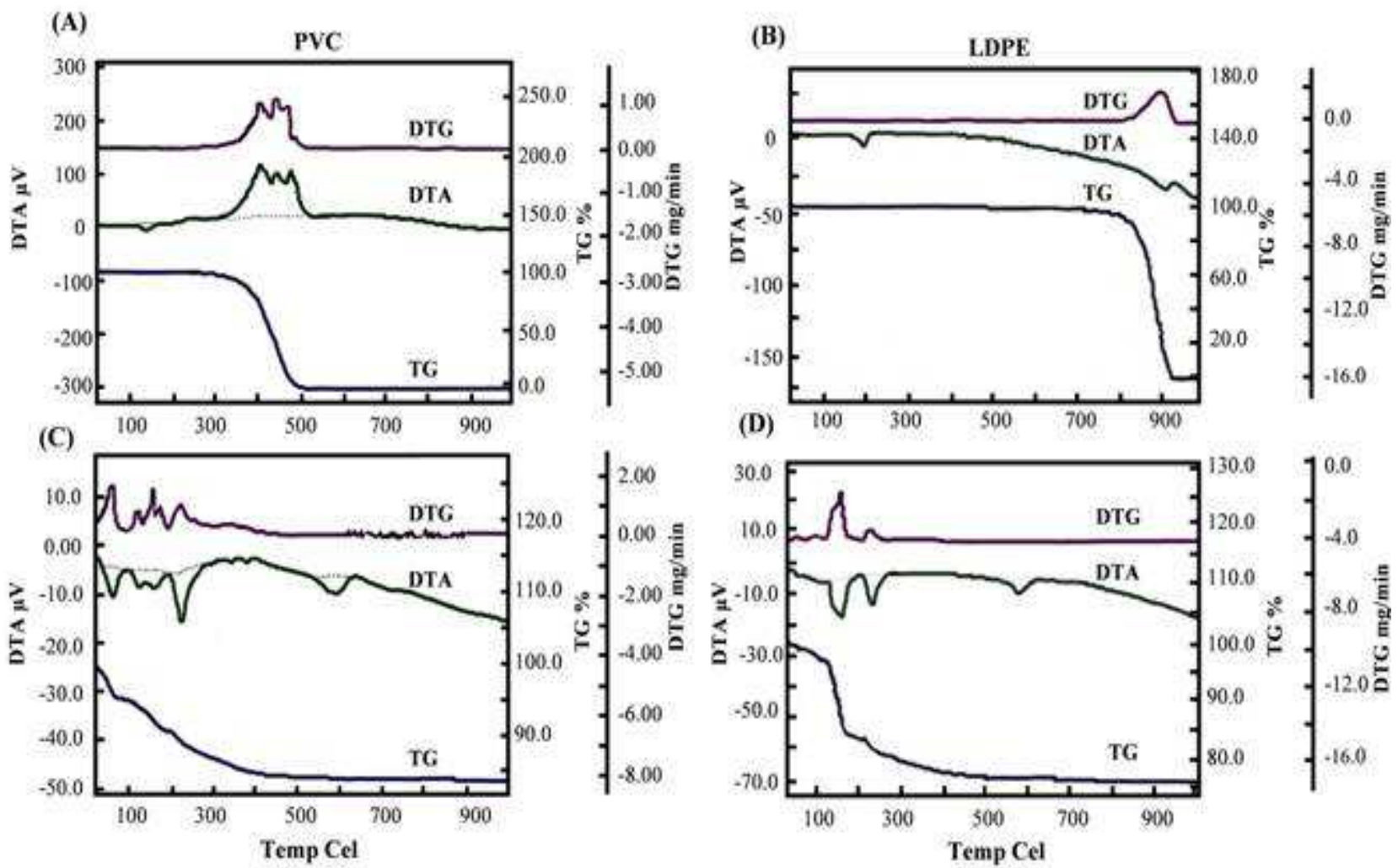

Figure 2 - Comparative TG -DTG-DTA thermogram of treated PVC (C) and LDPE (D) with reference to their control (A) and (B), respectively.

\section{FT-IR spectra}

The potential of consortium towards the biodegradation of PVC and LDPE powder was also reflected through the shift in the wave numbers $\left(\mathrm{cm}^{-1}\right)$ in comparison to the untreated one (Fig. 3). The changes in the polymers incubated in the presence of consortium were monitored in the range of 4000 to $450 \mathrm{~cm}^{-1}$. The control PVC powder (Fig. 3A) and film (Fig. 3B) showed characteristic wave numbers $\left(\mathrm{cm}^{-1}\right)$ at 2962.8 $2363.0\left(v \mathrm{CH}_{2}\right)$, , 1469.6-1463.0 $\left(\delta \mathrm{CH}_{2}\right), 1376.3-$ $1371.8(\delta \mathrm{CH}), 1084.7-1073.2(v \mathrm{C}-\mathrm{O}-\mathrm{C})$, and 745.9-721.5 (v C-Cl) as reported by Mekki and Belbechir (2007) for vinyl chloride-vinyl ether copolymers. Additional characteristic peaks reported at $\left(\mathrm{cm}^{-1}\right) 3455.9(v \mathrm{OH}), 1631.2(\delta \mathrm{OH})$, $535.6(\delta \mathrm{C}-\mathrm{C}-\mathrm{C})($ Fig. $3 \mathrm{~A})$ and at $1726.3(\vee \mathrm{C}=\mathrm{O})$, $1280.8(\gamma \mathrm{CH}), 1127.6(\delta \mathrm{C}-\mathrm{C}), 652.5(v \mathrm{C}-\mathrm{C}-\mathrm{C})$ 
(Fig. 3B) represented to PVC powder and film, respectively. Similar characteristic peaks were also reported by Ramesh and $\mathrm{Yi}$ (2008) in the plasticized PVC.

The PVC powder treated in the presence of consortium in the laboratory-scale showed characteristic wave number $\left(\mathrm{cm}^{-1}\right)$ corresponding to $3417.0(v \mathrm{OH}), 1663.0(\delta \mathrm{OH}), 1476.3\left(\delta \mathrm{CH}_{2}\right)$, 1094.9 ( $v$ C-O-C), 530.8 ( $\delta$ C-C-C), respectively. However, the biodeterioration of PVC was ascertained through the introduction of the additional wave numbers at 985.4 and $863.17 \mathrm{~cm}^{-1}$ corresponding to $\rho \mathrm{CH}_{2}$ and $\square \omega \mathrm{CH}_{2}$, respectively. The consortium imparted simultaneous absence of wave number of $v_{\text {as }} \mathrm{CH}_{2}$ group and increase in the transmittance of the $\mathrm{C}$ $\mathrm{O}-\mathrm{C}$ group over control PVC. The removal of $v \mathrm{C}$ $\mathrm{Cl}$ at $721.5 \mathrm{~cm}^{-1}$ depicted the removal of some chlorine atom from the treated sample (Fig.3A).

The PVC film treated in natural conditions using the bioformulation showed wave number $\left(\mathrm{cm}^{-1}\right)$ corresponding to $3450.7(v \mathrm{OH}), 2924.5$ to 2854.5 $\left(v \mathrm{CH}_{2}\right), 1463.8\left(\delta \mathrm{CH}_{2}\right), 1216.4(\gamma \mathrm{CH}), 1080.7(v$ $\mathrm{C}-\mathrm{O}-\mathrm{C}), 763.5$ ( $v \mathrm{C}-\mathrm{Cl})$ and 673.0 ( $v$ C-C-C), respectively (Fig. 3B). The consortium introduced the absorption corresponding to the formation of hydroxyl group on the macromolecular chain of the PVC as well as the absence of wave numbers corresponding to $\delta \mathrm{C}-\mathrm{C}$. The simultaneous shift in the wave numbers of various groups indicated the microbial action on the polymeric structure.

The control LDPE powder (Fig. 3C) and the film (Fig. 3D) showed characteristic wave numbers $\left(\mathrm{cm}^{-1}\right)$ absorptions corresponding to 3435.6-3426.0 $(v \mathrm{OH}), 3030.8\left(v_{\text {as }} \mathrm{CH}_{3}\right), 2930.5-2919.9\left(v_{\text {as }} \mathrm{CH}_{2}\right)$, 2850.6-2848.2 ( $\left(v_{\mathrm{s}} \mathrm{CH}_{2}\right), 2368.0-2342.2\left(\rho \mathrm{CH}_{2}\right)$, $2151.8\left(\delta \mathrm{CH}_{2}\right), 1595.1-1594.2(\delta \mathrm{OH}), 1465.5-$ $1461.5\left(\delta_{\mathrm{as}} \mathrm{CH}_{2}\right), 1352.6-1351.6\left(\delta_{\mathrm{s}} \mathrm{CH}_{3}\right)$ and 768.4-720.2 $\left(\rho \mathrm{CH}_{2}\right)$, respectively (Kapri et al. 2010). The FT-IR spectra of LDPE powder treated by the consortium in the laboratory rendered spectral absorptions corresponding to 3494.9 ( $v$ $\mathrm{OH}), 2923.4\left(v_{\text {as }} \mathrm{CH}_{2}\right), 2365.2\left(\rho \mathrm{CH}_{2}\right), 1570.5(\delta$ $\mathrm{OH}), \quad 1465.8\left(\delta_{\mathrm{as}} \mathrm{CH}_{2}\right)$, and $720.2\left(\rho \mathrm{CH}_{2}\right)$, respectively. However, this sample showed the absence of various absorptions corresponding to methyl and methylene groups as observed in the control LDPE at 3030.8, 2850.6, 2151.8 and
$1352.6 \mathrm{~cm}^{-1}$. The introduction of $1218.2\left(v_{\mathrm{as}} \mathrm{C}-\mathrm{O}-\right.$ $\mathrm{C})$ and $1071.6 \quad\left(v_{\mathrm{s}} \quad \mathrm{C}-\mathrm{O}-\mathrm{C}\right)$ frequencies was observed in the treated polymer due to the inclusion of $\mathrm{O}$ atoms into the hydrocarbon polymer backbone through the microbial action (Fig. 3C). The LDPE film treated in the presence of consortium also showed the absorptions corresponding to $3427.5(\mathrm{v} \mathrm{OH}), 2919.1\left(\mathrm{v}_{\mathrm{as}} \mathrm{CH}_{2}\right)$, $2852.8\left(v_{\mathrm{s}} \mathrm{CH}_{2}\right), 1601.1(\delta \mathrm{OH}), 1443.6\left(\delta_{\text {as }} \mathrm{CH}_{2}\right)$ and $770.2\left(\rho \mathrm{CH}_{2}\right)$, respectively. However, the introduction of the additional wave numbers corresponding to $1217.7\left(v_{\mathrm{as}} \mathrm{C}-\mathrm{O}-\mathrm{C}\right), 1066.7\left(v_{\mathrm{s}} \mathrm{C}-\right.$ $\mathrm{O}-\mathrm{C})$ and $3021.2\left(\mathrm{v}_{\mathrm{as}} \mathrm{CH}_{3}\right)$ and removal of 2342.2 $\left(\rho \mathrm{CH}_{2}\right), 1351.6\left(\delta_{\mathrm{s}} \mathrm{CH}_{3}\right)$ frequencies illustrated the deterioration of LDPE film sample after three months in the soil (Fig. 3D). The variations in the wave numbers in the polymers spectra revealed that both the polymer were used as sole carbon source during the incubation period. The relative potential of the consortium was reflected through the comparative FT-IR study of the treated PVC and LDPE in the whole spectral range $\mathrm{cm}^{-1}$. The shift in the wave numbers of the various functional groups and changes in the backbone of PVC $(\delta \mathrm{C}$ $\mathrm{C}-\mathrm{C}$ ) indicated that the consortium was more effective towards the degradation of PVC.

\section{Scanning electron microscopy}

The morphological changes on the surface of PVC and LDPE film due to the action of consortium were analyzed after incubation period of three months in natural condition (Fig.4). The control PVC revealed smooth and homogeneous morphology (Fig.4A). But in the case of LDPE film, some wrinkled structures in a diagonal fashion were observed, probably due to the pressure of soil burial (Fig. 4B). The exposure of both the film to consortium imparted heterogeneous morphology with widened fissure, leading to the formation of cavities with wrinkles and white globular areas. The SEM micrograph revealed that the formation of cavities with wrinkles and white globular areas were more widened and prominent in the PVC (Fig.4C) as comparison to LDPE film (Fig. 4D). Thus, the observations suggested the considerable surfacial deterioration of polymer by the virtue of consortium action. 

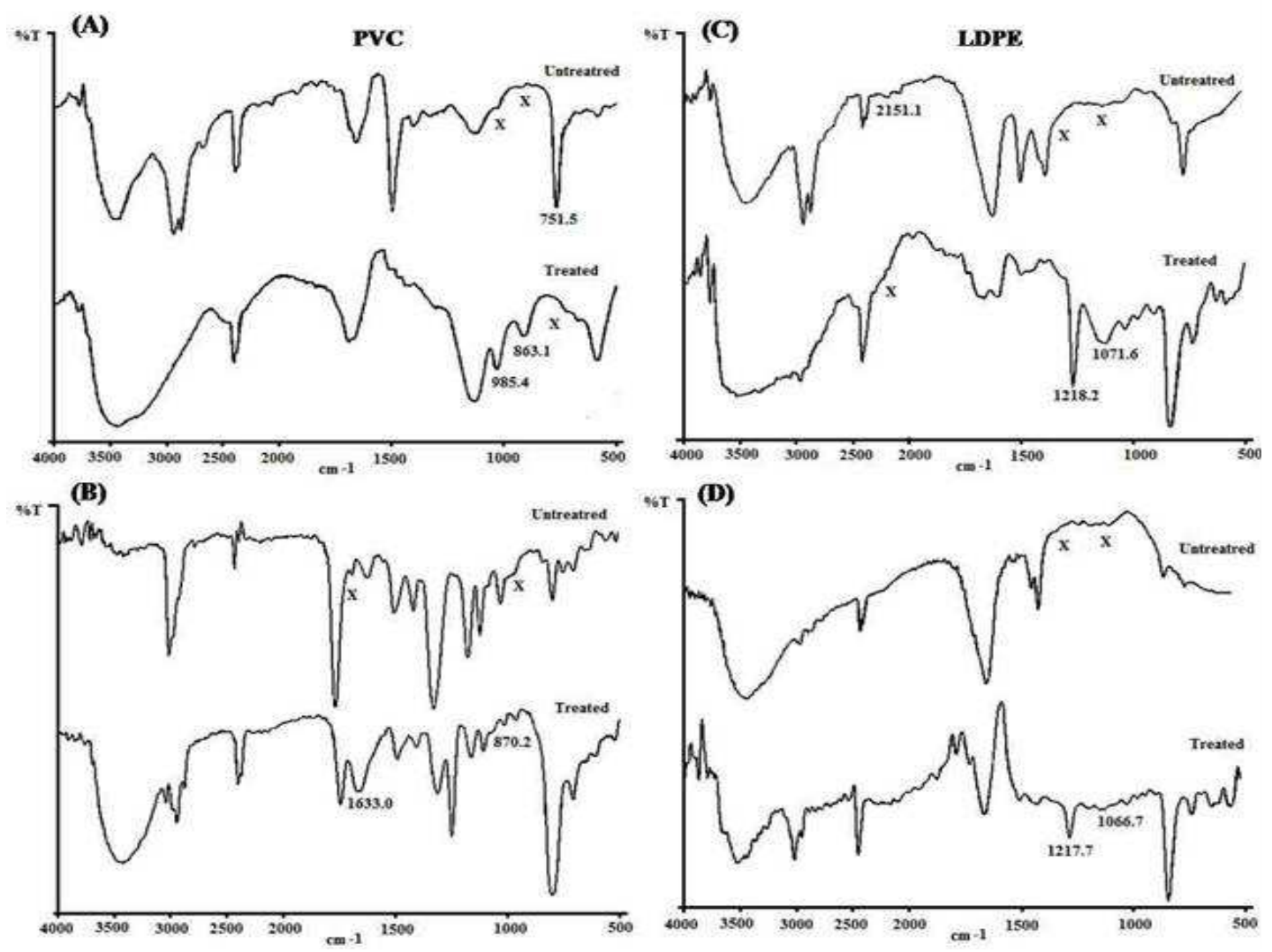

Figure 3 - Comparative FT-IR spectra of consortium treated PVC (A) and LDPE (C) powder in vitro and consortium treated PVC (B) and LDPE (D) film in natural conditions with reference to their controls.
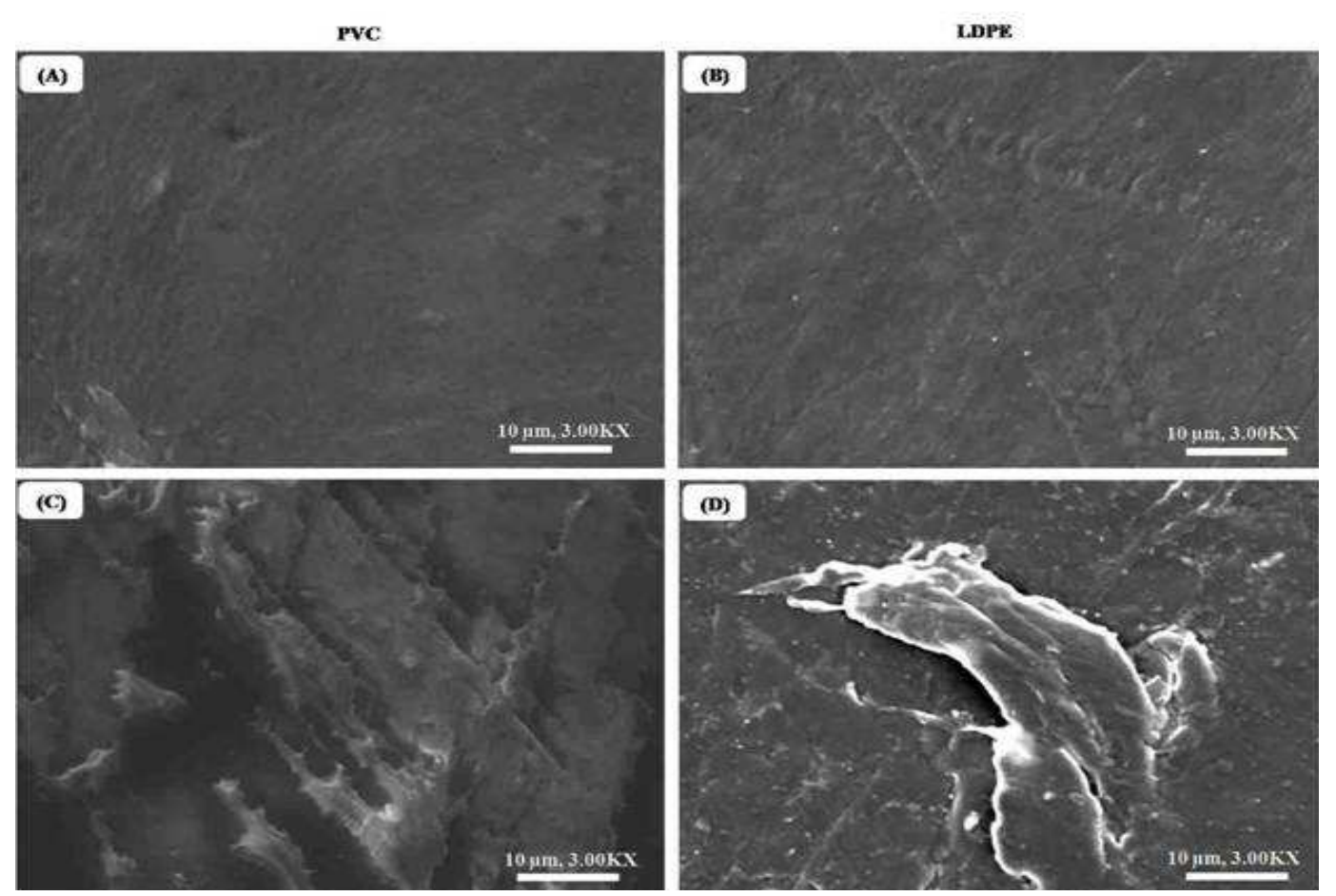

Figure 4 - SEM micrograph of consortium treated PVC (C) and LDPE (D) film in natural condition with references to their controls (A) and (B), respectively. 


\section{CONCLUSIONS}

This study explored the potential of indigenously developed bacterial consortium to degrade two thermoplastics, i.e., PVC and LDPE powder in broth and their film in the soil. Results revealed that the consortium was capable to act upon the PVC more efficiently than the LDPE. This could have been due to the higher bacterial colonization on the plasticizer content of the PVC. The bioformulation showed prolonged shelf-life and the biodeterioration efficacy of the polymers. Thus, the consortium could be considered for plastic-waste management strategies. This study also established a scale-up procedure with good reproducibility of plastic deterioration and degradation by using the bioformulations at the waste disposal site. This might enhance the capabilities of potential bacterial isolates to act upon, degrade and mineralize the thermoplastic waste on site.

\section{ACKNOWLEDGEMENT}

This work is supported by Department of Biotechnology grant to RG. We are also thankful to CDRI (SAIF), Lucknow, Instrumentation Centre, IIT Roorkee and College of veterinary and animal science, G.B.P.U.A \&T, Pantnagar for the FTIR, TG-DTG-DTA and SEM analysis, respectively.

\section{REFERENCES}

Anwar MS. Biodegradation studies of Poly vinyl chloride and Low density Polyethylene using indigenously developed microbial consortia $[\mathrm{PhD}$ Thesis]. Pantnagar, India: G.B.P.U. of Ag. \& Tech.; 2011.

Arora N.K, Khare E, Naraian R, Maheshwari DK. Sawdust as a superior carrier for production of multipurpose bioinoculant using plant growth promoting rhizobial and pseudomonad strains and their impact on productivity of Trifolium repense. Current Science. 2008; 12: 95.

Arutchelvi J, Sudhakar M, Arkatkar A, Doble M, Bhaduri S, Uppara PV. Biodegradation of polyethylene and prolypropylene. Indian $J$. Biotechnol. 2008; 7: 9-22.
Barnes DAK, Galgani F, Thompson, RC, Barlaz, M. Accumulation and fragmentation of plastic debris in global environment. Phil. Trans. R. Soc. B. 2009; 364: 1985-1998.

Booth GH, Robb JA. Bacterial degradation of plasticised PVC-effect on some physical properties. , Int. J. Appl. Chem. 2007; 18: 194-197.

Goel R, Zaidi MGH, Soni R, Lata K, Shouche YS. Implication of Arthrobacter and Enterobacter species for polycarbonate degradation. Intern. Biodet. Biodeg. 2008; 61: 167-172.

Goel R, Kapri A, Satlewal A, Negi H, Zaidi MGH. Formulation of bacterial consortium for degradation of high-density polyethylene. DBT, India, Application No. 1290/Del/2010.

Goel R, Sah A, Negi H, Kapri A. Preparation of talc based formulation of LDPE biodegrading consortia for field application. DBT, India, Application No. 213/DEL/2011.

Gupta SB, Ghosh A, Chowdhury T. Isolation and selection of stress tolerant plastic loving bacterial isolates from old plastic wastes. World J. Agric. Sci. 2010; 6: 138-140.

Kapri A, Zaidi MGH, and Goel R. Implications of SPION and NBT nanoparticles upon in-vitro and insitu biodegradation of LDPE film. J. Microbiol. Biotechnol. 2010; 20: 1032-1041.

Kathiresan K. Polythene and plastics-degrading microbes from the mangrove soil. Rev. Biol. Trop. 2003; 51: 629-634.

Kawai F. The biochemistry and molecular biology of xenobiotic polymer degradation by microbes. Biosci., Biotechnol. and Biochem 2010; 74:1743-1759.

Mekki H, Belbachir M. Preparation of vinyl chloridevinyl ether copolymers via partial etherification from PVC. Express Polymer Lett. 2007; 1: 495-498.

Nakamiya K, Hashimoto S, Edmonds JS, Yasuhara A, Morita M. Microbial treatment of bis (2-ethylhexyl) phthalate in polyvinyl chloride with isolated bacteria. J. Biosci. Bioeng. 2005; 99: 115-119.

Nowak B, Pajak K, Drozd-Bratkowicz M, Rymarz G. Microorganisms participating in the biodegradation of modified polyethylene films in different soils under laboratory conditions. Int. Biodeter. Biodeg. 2011; 65(6): 757-767.

Ramesh S, Yi,LM. FT-IR spectra of plasticized high molecular weight PVC-LiCF $3 \mathrm{SO}_{3}$ electrolytes. Ionics. 2008; 15: 413-420.

Sah A, Kapri A, Zaidi MGH, Negi H, Goel R. Implications of Fullerene-60 upon in- vitro LDPE biodegradation. J. Microbiol. Biotechnol. 2010; 20: 908-916.

Sandra M, Franchetti M, Egerton TA, White JR. Morphological changes in poly (caprolactone)/poly (vinyl chloride) blends caused by biodegradation. $J$. Polymer Environ. 2010; 18: 79-83. 
Shanmugam V, Kanoujia N, Singh M, Singh S, Prasad R. Biocontrol of vascular wilt and corm rot of gladiolus caused by Fusarium oxysporum $f$. sp. gladioli using plant growth promoting rhizobacterial mixture. Crop protection. 2011; doi: 10.1016/j. cropro.2011.02.033.

Sharon C, Sharon M. Studies on Biodegradation of Polyethylene terephthalate: A synthetic polymer. $J$. Microbiol. Biotech. Res. 2012; 2(2): 248-257.

Tajeddin B, Rahman RA, Abdulah LC, Ibrahim NA, Yusof YA. Thermal properties of low density polyethylene-filled kenaf cellulose composites. Eur. J. Sci. Res. 2009; 32(2): 223-230.

Ting ASY, Fang MT, Tee CS. An in-vitro assessment on the efficacy of clay-based formulated cells of Pseudomonas isolate UTAR EPA2 for petrol degradation. Am. J. Appl. Sci.. 2010; 7: 178-184.

Webb JS, Nixon M, Eastwood IM, Greenhalgh M, Robson GD, Handley PS. Fungal colonization and biodeterioration of plasticized polyvinyl chloride. Appl. Environ. Microbiol. 2000; 66: 3194-3200.
Wypych G. PVC degradation and stabilization. 2nd ed. ChemTech Publishing: Toronto; 2008.

Yoon MG, Jeon H J, and Kim MN. Biodegradation of Polyethylene by a Soil Bacterium and AlkB Cloned Recombinant Cell. J. Bioremed. Biodegrad. 2012; 3(4): 145. doi:10.4172/2155-6199.1000145.

Zeng F, Cui K, Fu J, Sheng G, Yang, H. Biodegradation of di(2-ethylhexyl) phthalate by Pseudomonas fluorescens FS1. Water Air Soil Pollut. 2002; 140: 297-305.

Received: March 25, 2012; Revised: October 05, 2012; Accepted: May 13, 2013. 